\title{
METAL-ENZYME JUNCTION PROPERTIES IN GASEOUS SURROUNDINGS: CONVERSION OF BIOCHEMICAL REACTION INTO ELECTRICAL SIGNAL
}

\author{
V. Bukauskas ${ }^{\text {a }}$, A. Mironas ${ }^{\text {a }}$, V. Strazdienė ${ }^{\text {a }}$, A. Šetkus ${ }^{\text {a }}$, V. Laurinavičius ${ }^{\text {b }}$, \\ R. Meškys ${ }^{b}, J_{\text {. Razumienè }}{ }^{b}, S$. Kačiulis ${ }^{c}$, and A. Mezzi ${ }^{c}$ \\ ${ }^{a}$ Semiconductor Physics Institute, A. Goštauto 11, LT-01108 Vilnius, Lithuania \\ E-mail: mironas@pfi.lt \\ ${ }^{\mathrm{b}}$ Institute of Biochemistry, Mokslininku 12, LT-2600 Vilnius, Lithuania \\ ${ }^{\mathrm{c}}$ Istituto per lo Studio dei Materiali Nanostructurati ISMN-CNR, P.O. Box 10, I-00016 Monterotondo Stazione (RM), Italy
}

Received 28 November 2006

\begin{abstract}
Planar sensors capable to detect ethanol and 1,2-propanediol vapour in air after special activation are constructed of technologically symmetrical contacts Metal / Alcohol Dehydrogenase (ADH) / Metal. The active ADH layers are self-assembled from a colloidal solution of enzyme after the drying at laboratory conditions. Electrical and surface properties and the response to the tested vapours are investigated in two types of pyrroloquinoline guinone dependent ADH-dry-layer sensors based on soluble ADH from Pseudomonas Putida HK-5 (ADH-II) and membrane type ADH from Gluconobacter sp 33 (ADH-III).
\end{abstract}

Keywords: biosensors, ethanol vapour sensor, 1,2-propanediol vapour sensor

PACS: $73.25 .+\mathrm{i}, 73.20 .-\mathrm{r}, 85.80 .-\mathrm{b}$

\section{Introduction}

Various types of biomolecules were used for development of chemical detectors in numerous studies [1-3]. Typically bio-sensors generate an electrical signal in response to the target chemicals in liquid medium because extra electrical charge is transferred from the biological components to the electrodes as a result of the biochemical interaction in these detectors. The mechanism and the characteristics of this transfer depend not only on the biomolecule type but also on the immobilization of the molecule on the electrodes. The biomolecular structures, such as pyrroloquinoline quinine (PQQ)-dependent alcohol dehydrogenase $(\mathrm{ADH})$, where the response mechanism is determined by direct electron transfer to electrode $[4,5]$, are highly attractive for development of miniaturized practical devices. Recently, we introduced an original method acceptable for predictable change of the state of membrane type PQQ-dependent ADH and the characteristics of electron transfer [6,7]. The aim of this study was to investigate the activation possibility of another PQQ dependent enzyme-soluble alcohol dehydrogenases (ADH-II) using this method.

\section{Experimental}

In our study, metal-enzyme junctions for experimental tests were manufactured by combining thin film technology and deposition from a liquid solution. Planar metallic electrodes were shaped from thin metallic films by standard photolithography on an insulating base-plate (e.g. glass or $\mathrm{Si}+\mathrm{SiO}_{2}$ ). Metallic films of $\mathrm{Pt}, \mathrm{Au}$, and $\mathrm{Ag}$ sputtered by dc magnetron technique were the basis of strip-like electrodes. The gap between the electrodes was in the range from about 0.6 to $10 \mu \mathrm{m}$.

On the top of the insulating plate with the metallic electrodes, an active layer was deposited from liquid solution of enzyme. Two different types of PQQdependent ADH were used. The investigated layers were deposited from colloidal solutions of soluble pyrroloquinoline guinone dependent alcohol dehydrogenase from Pseudomonas Putida HK-5 (ADH-II) and membrane type ADH from Gluconobacter sp 33 (ADH-III). Individual buffer solutions based on potassium phosphate $\left(\mathrm{KH}_{2} \mathrm{PO}_{4}: \mathrm{NaOH}\right)$ and tris- $\mathrm{HCl}$ $\left(\left(\mathrm{HOCH}_{2}\right)_{2} \mathrm{CNH}_{2}: \mathrm{HCl}\right)$ were used for ADH-III and ADH-II respectively. The structures were selfassembled after the drying at laboratory conditions, 
characterized by environmental temperature of about 293-295 K and relative air humidity (RH) of about 35$45 \%$.

The electrical properties of the manufactured structures and response to tested gas were investigated in the experiments in which a dc voltage drop was measured on the load resistance connected in series to a $\mathrm{Me} / \mathrm{ADH} / \mathrm{Me}$ structure. During the dc electrical tests, an original method was used for the activation of the ADH molecules. The method is analogous to an electrical shock and was proposed in our previous report [7]. After the activation, the signal proportional to the current was periodically measured in the circuit without an external power source. Dependence of the signal on time was recorded for the structures after exposure to controllable amount of tested vapour in synthetic air. The response tests were performed in computerized gas flow control system. In this system, the structures were mounted in the tube-like chamber with practically zero dead-volume. Synthetic air was used as the carrier gas and it was flowing at the constant rate (typically about $200 \mathrm{ml}$ per minute) through the chamber. Controlled amount of ethanol and 1,2-propanediol vapour was individually injected into the carrier gas flow at separated periods of the tests. The amount of injected vapour was maintained stabile in the flow until the end of the measurement of the particular response.

The surface chemical composition of the layers was analyzed by using X-ray photoelectron spectroscopy (XPS). This analysis was performed at two detection angles, namely 90 and $45^{\circ}$. The chemical composition throughout the film thickness was investigated by combining the XPS analysis and cyclic $\mathrm{Ar}^{+}$-ion etching $\left(E_{\mathrm{i}}=2.0 \mathrm{keV}\right)$. The sample holder was cooled by liquid nitrogen during the XPS measurements and $\mathrm{Ar}^{+}$-etching.

\section{Results}

After the ADH layers have been dried in ambient atmosphere, temporary connection of an external power source was used to activate the contacts between the electrode metal and ADH molecule in the planar $\mathrm{Me} / \mathrm{ADH} / \mathrm{Me}$ structures. After the activation, the junctions generated an electrical signal in response to ethanol (1,2-propanediol) vapour. This response was recorded in unlimited number of cycles, each of which consisted of four periods, namely activation, waiting, responding, and restoring. The sequence of the measured signals was described in detail in our previous report [7]. These cycles can be repeated during compara-

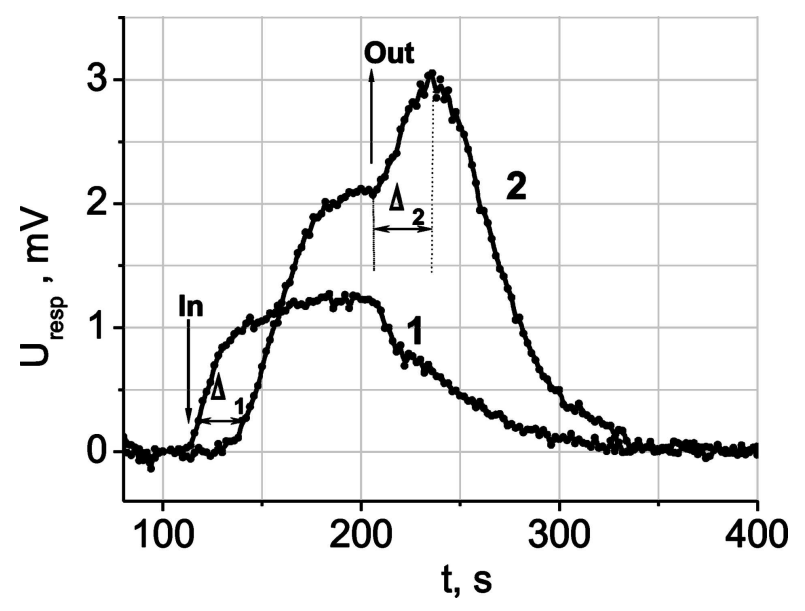

Fig. 1. Extra current response of two different types ADH-drylayers, ADH-III (1) and ADH-II (2), to ethanol of $4.4 \%$ vapours in air (relative humidity $\mathrm{RH}=43 \%$ ). The gap between the $\mathrm{Au}$ electrodes was about $6 \mu \mathrm{m}$, external activation voltage $U_{0}=4.2 \mathrm{~V}$.

tively long time (of about 15-20 days). The response is typically measured as an extra electrical current that appears without any electrical power source in the external circuit. Typical response signals to ethanol vapour of $\mathrm{Au} / \mathrm{ADH} / \mathrm{Au}$ structures are illustrated in Fig. 1.

Individual variation of the electric signal with time was recorded for each type of the enzyme based structures during temporary exposure of the structures to constant amount of ethanol vapour in air. A time delay between the rises of the responses was detected for the ADH-II based layer after exposure to ethanol vapour in air $\left(\Delta_{1}\right.$ in Fig. 1). A time delay between the falls of responses was also found after the clean air was restored in the sensor chamber $\left(\Delta_{2}\right.$ in Fig. 1). In general, $\Delta_{1}$ and $\Delta_{2}$ were not the same.

The most unexpected variation of the ADH-II response to ethanol was found during the transition from the contaminated air to the clean air atmosphere. A spike was typically recorded just before the fall of the response of the ADH-II layers to ethanol vapour immediately after the clean air was abruptly restored in the test chamber (2 in Fig. 1). There were no analogous variations of the response of ADH-III structures to ethanol over the period from injection of ethanol until purging it out ( 1 in Fig. 1).

The response of the ADH-dry-layer sensors was highly dependent on the temporary activation by the external voltage. Typical dependences of the extra current response to ethanol (1,2-propanediol) on the magnitude of the activation voltage are illustrated in Fig. 2.

Taking into account the fact that the ADH molecules were deposited from the colloidal solution, it can be supposed that the influence of the external activation voltage on the response signal can partly be related 


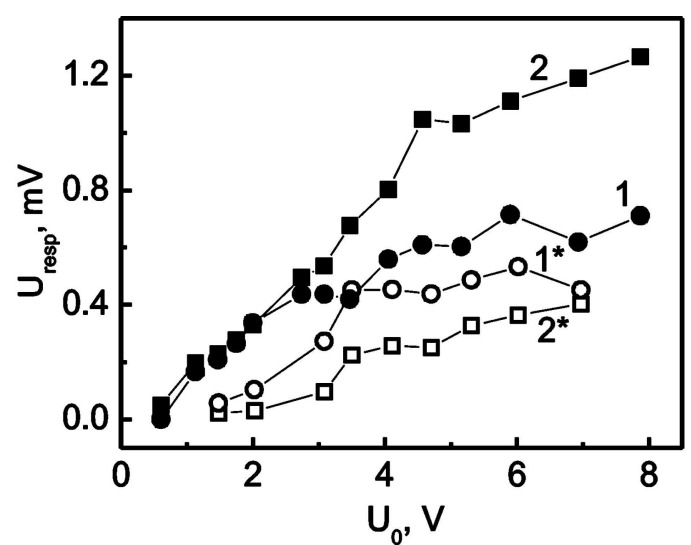

(a)

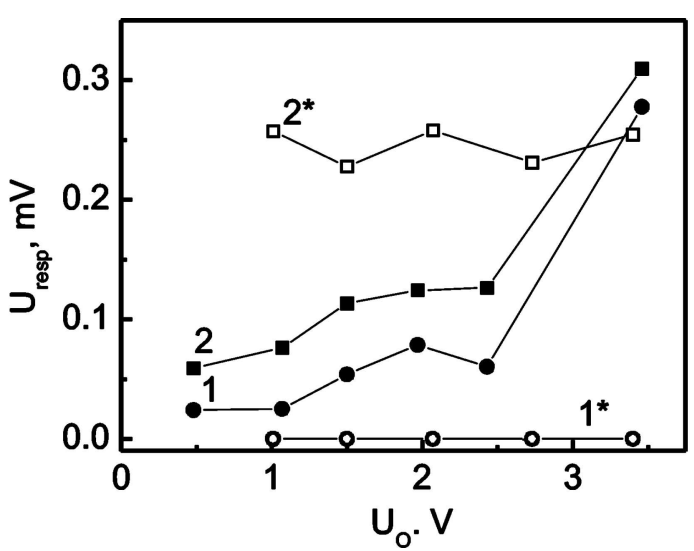

(b)

Fig. 2. Dependence of the extra current response of the ADH-dry-layer sensors ( $1,1 *$ for ADH-III and 2, $2 *$ for ADH-II) to (a) ethanol and (b) 1,2-propanediol vapour in air on the temporary voltage $U_{0}$ applied to the electrodes for the ADH activation. The ADH-dry-layers were "as deposited" from the colloidal solution $(1,2)$ and after the buffer residue was washed out $\left(1^{*}, 2 *\right)$.

to the residues of the buffer solution. The supposition seemed be supported by noticeable response of the Me/ADH-III/Me structures to the vapour of 1,2-propanediol (Fig. 2(b)). Taking into account extremely high selectivity of ADH-III molecules to ethanol such results seems unexpected.

Aiming to describe the effect of the residue the $\mathrm{Me} / \mathrm{ADH} / \mathrm{Me}$ structures were investigated right after drying of the layer and after special rinsing of the samples.

Typical dependence of the response of rinsed and not rinsed structures on the activation voltage is illustrated in Fig. 2. The response to ethanol (Fig. 2(a)) and 1,2-propanediol (Fig. 2(b)) was measured for the structures. The response to ethanol was practically not changed by washing out the residues from the dry ADH-III layers. Only some decrease in the magnitude of the response signal can be associated with the rinsing in this experiment. In contrast to this, the response to 1,2-propanediol was much more affected by the additional procedure of the structure preparation. After washing out the residues, the response of the ADH-III structures to 1,2-propanediol drastically decreased and was below the noise level in the measurement circuit (about $5 \cdot 10^{-7} \mathrm{~V}$, label $l$ in Fig. 2(b)).

As followed from the XPS analysis the interfaces between the metals and enzymes are completely covered by the compounds of the ADH layer. Rinsing the samples with distilled water did not clear the metal surfaces, while the residue of buffer solution was completely washed out. These facts are illustrated by XPS spectra presented in Fig. 3, where the three components of $\mathrm{C} 1 s$ peak are characteristic of $\mathrm{ADH}$. These components correspond to the $\mathrm{C}-\mathrm{C}(285.0 \mathrm{eV}), \mathrm{C}-\mathrm{OH}$ $(286.5 \mathrm{eV})$, and $\mathrm{C}-\mathrm{O}$ or $\mathrm{C}-\mathrm{NO}(288.1 \mathrm{eV})$ bonds and

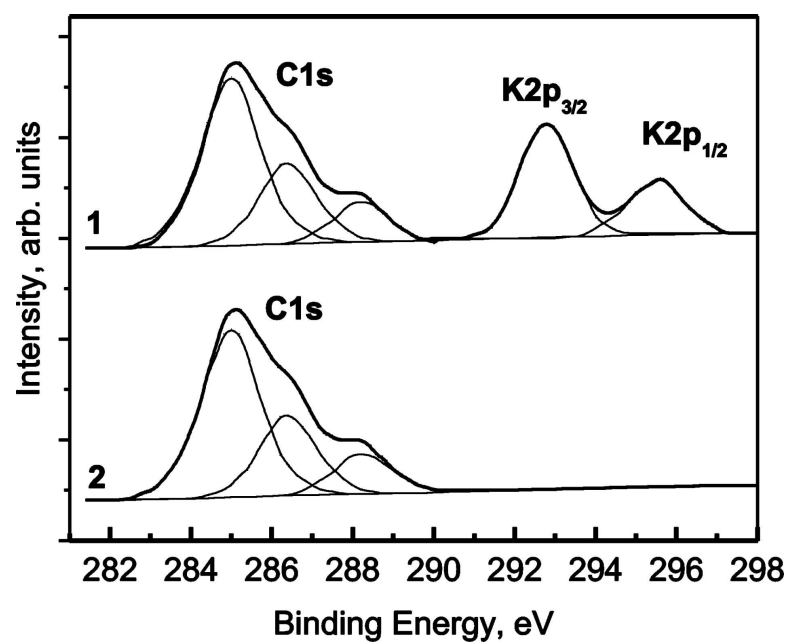

Fig. 3. XPS spectra registered before (1) and after (2) removal of buffer residuum from ADH-II layers by rinsing in distilled water. Three components of $\mathrm{C} 1 s$ peak correspond to the $\mathrm{C}-\mathrm{C}(285.0 \mathrm{eV})$, $\mathrm{C}-\mathrm{OH}(286.5 \mathrm{eV})$, and $\mathrm{C}-\mathrm{O}$ or $\mathrm{C}-\mathrm{NO}(288.1 \mathrm{eV})$ bonds and all together make the XPS fingerprint of the enzyme; K $2 p$ peak corresponds to buffer residue.

all together make the XPS fingerprint of the enzyme. After rinsing, the $\mathrm{K} 2 p$ peak (buffer residue marker) completely disappears, while the shape and intensity of $\mathrm{C} 1 s$ peak (XPS fingerprint of ADH) remains stable. Therefore, it can be supposed that the rinsing should eliminate an influence of the buffer on the characteristics of the $\mathrm{Me} / \mathrm{ADH} / \mathrm{Me}$ structures.

The signals of the response of the ADH layers were typically proportional to the partial pressure of alcohol vapour in air. Different types of the enzyme structures were characterized by individual sensitivity to the same alcohol vapour. The dependences of the response on the partial pressure of alcohol vapour were described 


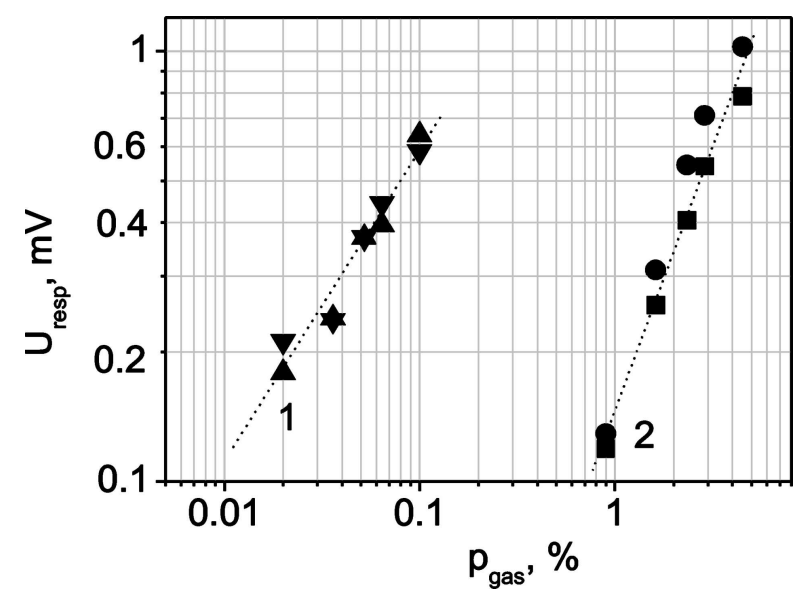

Fig. 4. Dependences of the responses of ADH-II layer samples on amount of 1,2-propanediol (1) and ethanol (2) vapour in air after the temporary activation with external voltage $U=4.2 \mathrm{~V}$. Ambient temperature $T=295 \mathrm{~K}$, relative humidity $\mathrm{RH}=43 \%$. Lines are $U_{\text {resp }} \sim p_{\text {gas }}^{x}$ with $x=3 / 5(1)$ and 3/2 (2).

by a power law $U_{\text {resp }} \sim p_{\text {gas }}^{x}$. Typical dependences measured for ADH-II layers are illustrated in Fig. 4.

It followed from experimental results in Fig. 4 that ADH-II layers were characterized by individual sensitivities $\left(\Delta U_{\text {resp }} / \Delta p_{\text {gas }}^{x}\right)$ to ethanol and 1,2-propanediol. The sensitivity of ADH-II layers is significantly higher to ethanol $(x=3 / 2$, Fig. 4,2$)$ than to 1,2-propanediol ( $x=3 / 5$, Fig. 4,1$)$. In contrast to the sensitivity, the lowest detectable amount of 1,2-propanediol is much more lower (less than $100 \mathrm{ppm}$ ) than that of ethanol (about 500-700 ppm). The lowest detectable amount is defined from comparison of the measurable response signal with the noise level in the measurement circuit. Analogous dependence was obtained in the investigation of ADH-III layers exposed to ethanol vapour [7].

On the other hand, the response time decreases with amount of tested liquid vapour in the air (Fig. 5). Actual response time, including delay $\left(\Delta_{1}\right.$ in Fig. 1) is about one minute.

\section{Conclusion}

The structures based on symmetric junctions between enzyme and metallic electrode are activated by temporary connection of electric voltage to the electrodes at least for the ADH-III and ADH-II enzymes. The activation routine produces a chemically sensitive state in the system that electrically responds to tasted vapour without an external power source. Based on the tests performed for the two types of enzymes we suppose that analogous sensitive states can be obtained in the structures containing various enzymes in which di-

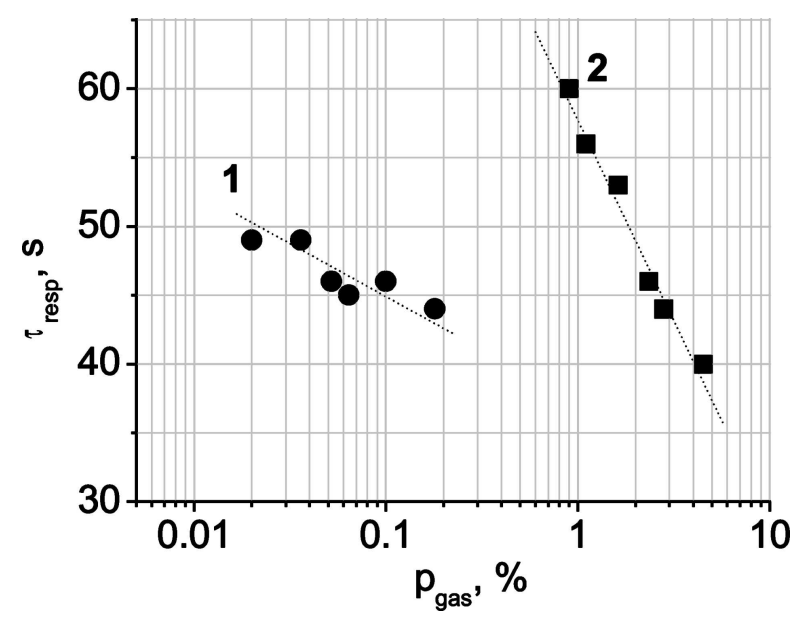

Fig. 5. Response time of ADH-II samples on amount of 1,2-propanediol (1) and ethanol (2) vapour in air after the temporary activation with external voltage $U=4.2 \mathrm{~V}$. Surroundings as in Fig. 4.

rect electron transport from biomolecule to electrode is possible.

The response of planar Me / $\mathrm{ADH} / \mathrm{Me}$ structures to alcohol vapour can be increased if residual components of buffer solution are not removed from ADH based structures. On the other hand, the selectivity of impure enzyme layer is significantly less than that of ADH layers without buffer residual compounds. Assuming that the electron transport is hardly possible between two molecules, it seems reasonable to suppose that the response of pure enzyme layers is diminished by inactive enzymes heaped up on the bottom monolayer of ADH particles. By considering the rind of the top molecules that screens the bottom molecules from direct access of gas particles, one can understand a delay between the injection of the vapour and the rise of the response if the delay is detected for the both ADH types. Significant delay between the responses of ADH-III and ADH-II to alcohol can hardly be associated with an overlayer of inactive biomolecules. At present state of investigation, it is not clear what is the origin of the delay, especially considering the fact that an electron path from PQQ centre to electrodes has to be shorter in ADH-II enzyme which is smaller than ADH-III.

\section{References}

[1] R. Rogers, Recent advances in biosensor techniques for environmental monitoring. Review, Anal. Chim. Acta 568, 222-231 (2006).

[2] S. Serbana and N. El Murr, Redox-flexible NADH oxidase biosensor: A platform for various dehidrogenase bioassays and biosensors, Electrochim. Acta 51, 51435149 (2006). 
[3] J.J. Gooding, Biosensor technology for detecting biological warfare agents: Recent progress and future trends. Review, Anal. Chim. Acta 559, 137-151 (2006).

[4] V. Laurinavičius, J. Razumienè, A. Ramanavičius, and A.D. Ryabov, Wiring of PQQ-dehydrogenases, Biosensors Bioelectron. 20, 1217-1222 (2004).

[5] J. Razumienè, A. Vilkanauskytè, V. Gurevičienè, J. Barkauskas, R. Meškys, and V. Laurinavičius, Direct electron transfer between PQQ dependent glucose dehydrogenases and carbon electrodes: An approach for electrochemical biosensors, Electrochim. Acta 51, 5150-5156 (2006).

[6] A. Šetkus, J. Razumienè, A. Galdikas, V. Laurinavičius, R. Meškys, and A. Mironas, Electrically in- duced gas sensitive state of enzyme-metal contact in ADH-dry-layer based planar structure, Sensors Actuators B: Chem. 95, 344-351 (2003).

[7] A. Galdikas, V. Laurinavičius, R. Meškys, A. Mironas, J. Razumiené, and A. Šetkus, Hybrid sensors for ethanol detection in air based on dry ADH layers, Lithuanian J. Phys. 42, 347-353 (2002).

[8] A. Galdikas, V. Bukauskas, S. Kačiulis, V. Laurinavičius, R. Meškys, A. Mezzi, A. Mironas, J. Razumienè, and A. Šetkus, Properties of the planar ADH-dry-layer structures based on electrically controlled coupling between enzyme molecules and metal surfaces, Sensors Actuators B: Chem. 118, 60-66 (2006).

\title{
METALO IR FERMENTO SANDŪROS SAVYBĖS DUJINĖJE APLINKOJE. ATSAKO İ BIOCHEMINE SĄVEIKĄ VIRTIMAS ELEKTRINIU SIGNALU
}

\author{
V. Bukauskas ${ }^{a}$, A. Mironas ${ }^{a}$, V. Strazdiené ${ }^{a}$, A. Šetkus ${ }^{a}$, V. Laurinavičius ${ }^{b}$, R. Meškys ${ }^{b}$, J. Razumiené $^{b}$, \\ S. Kačiulis ${ }^{c}$, A. Mezzi ${ }^{c}$ \\ ${ }^{\text {a }}$ Puslaidininkiu fizikos institutas, Vilnius, Lietuva ${ }^{\text {b }}$ Biochemijos institutas, Vilnius, Lietuva \\ ${ }^{\mathrm{c}}$ Nanosandaros medžiagu tyrimo institutas, Monterotondo Stacione, Italija
}

\section{Santrauka}

Naudojant plokščius simetriškus kontaktus metalas-alkoholio dehidrogenazè (ADH)-metalas, sukurti jutikliai, galintys po aktyvinimo išoriniu elektriniu lauku aptikti etanolio ir 1,2 propandiolio garus ore. Aktyvus ADH sluoksnis buvo formuojamas iš koloidi- nio fermento ir buferio tirpalo, džiovinant ji laboratorijos sąlygomis. Ištirtos sausų sluoksnių iš nuo pirolo chinolinchinono priklausomu alkoholio dehidrogenazių - tirpios (ADH-III) ir membraninès (ADH-II) - paviršiaus savybès ir elektrinis atsakas i etanolio ir 1,2 propandiolio garus ore. 